\title{
PELATIHAN MANAJEMEN KOMUNIKASI APARAT KELURAHAN DALAM PENANGANAN COVID-19 DI KEL. KAMBU, KEC. KAMBU KOTA KENDARI
}

${ }^{1}$ La Iba, ${ }^{2}$ La Ode Harjudin, ${ }^{3}$ Darpin, ${ }^{4}$ La Ode Jumaidin, ${ }^{5}$ Saidin

${ }^{12345}$ Fakultas Ilmu Sosial dan Ilmu Politik, Universitas Halu Oleo

Jl. HEA Mokodompit, Kampus Bumi Tridharma Anduonohu, Kendari 93232

\section{RINGKASAN}

Permasahan Negara atau dunia saat ini mewabahnya Covid-19 atau virus corona yang membuat pemerintah dalam mengambil tindakan dan kebijakan antara pemerintah pusat dan daerah kurang bersinergi yang mengakibatkan carut marutnnya dan minimnya manajemen sehingga tidak terkelola dengan baik ini sebabkan oleh manajemen komunikasi yang kurang sehat sehingga masyarakat menerimah informasi yang tidak sempurna (Hoaks), public di buat gelisah dan reaktif. Media sebagai alat informasi masyarakat dalam mengisi ruang dan waktu serta mengarahkan pikiran, perasaan termasuk aktivitas khalayak, media selalu akan menempatkan posisinya sebagai rujukan, acuan dan petunjuk dalam membentuk persepsi, orientasi dan aksi dalam dunia nyata. Rendahnya pengetahuan aparat kelurahan dalam hal manajemen Komunikasi dan alat peraga komunikasi dalam pencegahan penyebaran virus Covid-19 yang membuat masyarakat tidak memiliki pengetahuan tentang bahaya Covid-19 dapat kita saksikan bahwa masi banyak masyarakat tidak mengikuti anjuran pemerintah sebagaimana protokol dalam pencegahan covid-19 atau virus Corona.

\section{Kata kunci: manajemen; komunikasi; penanganan; Covid-19}

\section{A. Analisis Situasi}

Undang-undang Nomor 32 Tahun 2004 Tentang Pemerintahan Daerah diberi kewenangan dalam bentruk keleluasan terhadap pengambilan kebijakan maupun keputusan guna mendukung kualitas pelayanan public. Undang-Undang tersebut sekaligus membuka peluang kepada berbagai elemen masyarakat untuk berpartisipasi aktif, langsung maupun tak langsung Baik dalam pengembangan pembangunan sarana prasarana pusat hingga pedesaan. Berbagai cakupan dalam undang-undang tersebut mulai dari system ataupun proses administrasi sampai pada masalah kewenangan. Menurut Smith; salah satu kontribusi undang-undang nomor 32 tahun 2004 yakni terbukanya peluang pada penerapan demokrasi yakni Political equality; yaitu terbukanya kesempatan kepada masyarakat untuk berpartisipasi dalam aktivitas politik ditingkat lokal. Keluwesan atau terbukanya demokrasi sampai pada masyarakat pedesaan 
kerapkali menimbulkan kebablasan sebagai berdampak terhadap pola pelayanan aparatur pedesaan dalam melaksanakan tugas sebagai fasilitator bagi masyarakat Desa. Dalam melaksanakan pelayanan administrasi pemerintahan maupun pelayanan public lainnya menjadi tidak konsumtif bagi masyarakat akibat tidak terkomunikasinya dengan baik.

Partisipasi aktif masyarakat harus pula diikuti dengan terbentuknya masyarakat sipil (civil society), yaitu masyarakat yang mampu membina hidupnya baik secara individu maupun kelompok, dalam Negara mereka, mampu berinteraksi dengen Negara secara independen (Gaffar: 1999). Maka untuk menuju pada civil society maka masyarakat yang mulanya terpasung dengan aturan bahkan terpinggirkan sehingga tidak memberi peluang masyarakat untuk berkarya sesuai potensinya. Dengan undang-undang nomor: 32 maka masyarakat yang semula tidak diberi ruang dalam pengambilan keputusan menyangkut kebijakan dalam hal pelayanan public, lebih dipandang sebagai obyek, maka dengan undang-undang nomor 32 tahun 2004, masyarakat lebih diberdayakan untuk terlibat sebagai pelaku atau subyek utamanya dalam menetapkan kebijakan, Kondisi tersebut menghendaki pengelolaan pembangunan yang lebih efektif.

Pembangunan di wilayah perkotaan sebagai bagian dari Negara Kesatuan Republik Idonesia berimbang sebagaimana halnya dengan pembangunan di wilayah perkotaan. Namun hal tersebut dapat diberdayakan masyarakat secara aktif apabila memiliki pola dalam membangkitkan semangat masyarakat, mengingat kemampuan dana yang dimiliki pemerintahan Desa kadang tidak berimbang dengan volume program pembangunan yang dibutuhkan masyarakat. Menyadari akan hal tersebut maka undang-undang yang mengatur penyelenggaraan Pemerintahan Daerah lebih membuka ruang gerak yang lebih luas terhadap pengaturan desa maupun Lembaga Kemasyarakatan yang ada di Desa. Apalagi pemahaman masyarakat tentang demokrasi yang relative rendah seringkali menciptakan kegagalan dalam melaksanakan perencanaan pembangunan desa. Oleh karenanya demokrasi menurut Kuntjaraningrat dapat diaplikasikan kepada masyarakat dengan baik apabila dilakukan secara; persuasi, penerangan, pendidikan, dan system peransangan. Lanjut dikatakan Alex Inkeles modernisasi terdiri dari dua aspek : (a) 
internal, yang meliputi: sikap, nilai, dan perasaan, dan (b) eksternal atau yang menyangkut lingkungan.

Dengan demikian baik undang-undang nomor 32, maupun pandangan ahli tersebut sangat menghormati system nilai yang berlaku dalam kebiasaan dan karakter masyarakat serta budaya setempat sehingga memberi peluang bagi masyarakat Desa yang disesuaikan dengan kondisi social budaya masyarakat setempat, tentu dengan mengindahkan segala bentuk aturan yang diberlakukan pada setiap masyarakat dalam kehidupan berbangsa dan bernegara sebagaimana ditetapkan dalam berbagai kebijakan maupun produk-produk hukum positif yang harus dipatuhi bersama oleh seluruh lapisan masyarakat sebagai warga Negara. Jika tidak terkomunikasi dengan baik demokrasi bukannya akan menjadi konstruktif, melainkan destruktif atau akan menjadi ancaman kelestarian sifat masyarakat Indonesia atau warga pedesaan dengan nuansa gotong royong.

Permasahan Negara atau dunia saat ini mewabahnya Covid-19 atau virus corona yang membuat pemerintah dalam mengambil tindakan dan kebijakan antara pemerintah pusat dan daerah kurang bersinergi yang mengakibatkan carut marutnnya dan minimnya manajemen sehingga tidak terkelola dengan baik ini sebabkan oleh manajemen komunikasi yang kurang sehat sehingga masyarakat menerimah informasi yang tidak sempurna (Hoaks), public di buat gelisah dan reaktif. Media sebagai alat informasi masyarakat dalam mengisi ruang dan waktu serta mengarahkan pikiran, perasaan termasuk akativitas khalayak, media selalu akan menempatkan posisinya sebagai rujukan, acuan dan petunjuk dalam membentuk persepsi, orientasi dan aksi dalam dunia nyata. Di kota kendari kasus virus Covid-19 semakin hari bertambah ini menjadi masalah serius yang perluh di tangani dengan segera kalau tidak ini akan mengakitkan wabah yang berbahaya dan mengancam jiwa manusia secara luas oleh karena itu perluh adanya pelatihan ini dapatkan berbagai informasi tentang manejemen komunikasi organisasi dalam penanganan virus ini mengalami berbagi kendala tehnis baik itu disebabkan oleh masyarakat maupun aparat kelurahan. 
Pelatihan aparat tentang Manajamen organisasi atau perangkat Kelurahan dalam rangka penanganan pendemik Covid-19 atau Virus Corona Kel Kambu Kecamatan Kambu Kota Kendari untuk mengasih berbagai kendala tehnis ini baik itu informasi yang tidak jelas melalui media sosial maupun melalui orang perorang yang menciptakan opini yang tidak benar. Hal tersebut penting dilakukan mengingat Masyarakat kelurahan tersebut masuk Wilayah Kota Kendari yang masuk dalam Zona merah dalam hal penyebaran Covid-19 atau virus Corona sehingga membutuhkan perhatian khusus dalam memberikan peran aktif terhadap penanganan agar tidak menyebar secara luas.

\section{B. Metode Pelaksanaan}

\section{Persiapan dan Rekrutmen Peserta}

- Persiapan

Pelaksanaan kegiatan pengabdian masyarakat dan Kuliah Kerja Nyata iniakan dilakukan beberapa tahap, yakni :

Tahap Pertama

Tahap pertama dimana tim pengabdian mulai mengurus perizinan secara administrative kepala pemerintah daerah mulai Camat, Lurah/Desa hingga ketua RT/RW setempat. Perizinan ini bersifat pemberitahuan tertulis sekaligus meminta kesediaan lembaga mitra yang dapat terlibat dalam kegiatan serta informasi kegiatan yang akan dilaksanakan. Tahapan ini juga termasuk pembekalan dan sosialisasi program, penandatangan kontrak kerja dari LPPM Universitas Halu Oleo. Tahap Kedua

Rekrumen peserta kegiatan dilakukan secara proporsional di kalangan mahasiswa sebanyak 21 orang. Di samping itu, dalam perekrutan peserta mempertimbangkan pernyataan kesediaan sebagai peserta.

Tahap Ketiga

Pada tahap ini, tim menyusun panduan teknis kegiatan dan menentukan waktu pembekalan materi mengenai COVID-19 sebagai fungsi dalam membentuk pengetahuan aparat kelurahan berbasis pelatihan manajemen komunikasi dan pelatihan peraga alat komunikasi kepada peserta mahasiswa secara online 
menggunakan aplikasi zoom dan whatsapp group yang telah dibentuk dan dipersiapkan. Pada tahap ini juga tom bersama peserta akan mendesaian poster, gambar dan video serta TOR (term of reference), pengenalan COVID-19 sebagai fungsi membentuk pengetahuan aparat dalam menangani penyebaran COVID-19. Tahap Keempat

Tahap ini merupakan tahap pelaksanaan kegiatan lapangan, dimana seluruh rencana, peserta dan lembaga mitra termasuk kebutruhan yang diperlukan secara online dengan menggunakan aplikasi zoom dan whatsaap group yang sengaja dibentuk, baik kepada peserta maupun mitra kegiatan sebagai kelompok sasaran yang dituju. Dosen akan memberikan materi kepada kelompok sasaran dalam hal ini mitra kegiatan yang dibantu oleh mahasiswa dalam bentuk tutorial, desain gambar, video, dan dokumen.

Persipan kegiatanan dimulai dengan pembentukan tim baik dari dosen pembimbing maupun dari mahasiswa yang akan mengikuti program pengabdian Kuliah Kerja Nyata (KKN) ini, adapun tahapan sebagai berikut :

1. Dimana persiapan Kuliah Kerja Nyata ( KKN ) tematik 2020 wajib mengikuti protokol pandemi covid 19 yang telah di terapkan oleh pemerintah dan yang sudah di jalankan oleh lingkungan masyarakat sekitar, dan sebagainya team mulai mengurus perizinan secara administratif kepada pemerintah daerah kelurahan/desa hingga ketua RT/RW setempat. Perizinan ini bersifat pemberitahuan tertulis sekaligus meminta kesediaan lembaga mitra yang dapat terlibat dalam kegiatan serta informasi kegiatan yang akan dilaksanakan. Tahapan ini juga termasuk pelatihan atau sosialisasi program yang akan di laksanakan.

2. Rekrutmen anggota kegiatan yang dilakukan secara proporsional dikalangan aparat kelurahan dan mahasiswa Kuliah Kerja Nyata ( KKN ) tematik 2020 Kelurahan Kambu Kecamatan Kambu Kota Kendari. Disamping itu, dalam perekrutan anggota mempertimbangkan pernyataan kesediaannya sebagai anggota dalam proses kegiatan Daring. 
3. Tim menyusun panduan teknis kegiatan dan menentukan waktu meating untuk materi pelatihan Manajemen Komunikasi Dalam Penanganan Virus Covid19.mengenal covid-19 sebagai fungsi dalam membentuk pengetahuan aparat kelurahan berbasis pelatihan manajemen komunikasi dan pelatihan peraga alat komunikasi kepada masyarakat Kelurahan Kambu Kecamatan Kambu Kota Kendari secara daring (online) dengan menggunakan aplikasi zoom meeting dan whatsapp group yang telah dibentuk dan dipersiapkan oleh dosen dan mahasiswa.

4. Agar dapat menjalankan fungsi dalam pelaksanaan kegiatan daring (online), dalam hal ini bagian umum untuk anggota Kuliah Kerja Nyata (KKN) untuk memastikan hal - hal sebagai berikut :

a. Melakukan identifikasi, siapa saja yang akan mengikuti pelaksanaan kegiatan daring (online).

b. Menentukan sumber daya peralatan yang dimiliki oleh Aparat kelurahan, apakah mereka mempunyai perlatan untuk melakukan pelatihan secara daring(online), seperti laptop/Hp, dan memiliki sambungan internet lancar, dsb.

c. Menentukan bagaimana pengawasan dan koordinasi dilakukan (koordinasi pembagian tugas).

d. Memastikan anggota dapat menggunakan perangkat/aplikasi untuk melakukan koordinasi jarak jauh dengan berbagai macam aplikasi yang telah tersedia.

e. Memantau kehadiran anggota dalam pertemuan yang dilaksanakan secara online/daring melalui aplikasi zoom meeting.

5. Untuk dapat mewujudkan work from home yang produktif, diperlukan komunikasi dan kerjasama yang baik dari seluruh pihak, khususnya dari pihak kelurahan dan anggota Kuliah Kerja Nyata (KKN), agar dapat meminimalisir faktor - faktor kendala yang mungkin terjadi. Dengan mengusung niat dan tujuan yang sama, yaitu Pelatihan Manajemen Komunikasi Dalam Penanganan 
Covid 19 atau Corona Virus, pelaksanaa work from home diharapkan tidak akan mengurangi tercapainya target kinerja yang telah diamanatkan oleh organisasi.

6. Tahap ini merupakan tahap pelaksanaan kegiatan lapangan yang dilakukan secara daring (online), dimana seluruh rencana, anggota Kuliah Kerja Nyata (KKN) dan Aparat Kelurahan termasuk kebutuhan yang diperlukan telah dipersiapkan dengan baik. Pelaksanaan kegiatan akan dikakukan secara online dengan menggunakan aplikasi zoommeeting dan whatshap group yang sengaja dibentuk, baik kepada peserta maupun mitra kegiatan sebagai kelompok sasaran yang dituju. Dosen akan memberikan materi kepada kelompok sasaran dalam hal ini mitra kegiatan yang dibantu oleh mahasiswa Kuliah Kerja Nyata (KKN) dalam bentuk tutorial, desain gambar, video dan dokumen sehingga harapan kami semoga output yang keluar dari pelatihan aparat kelurahan dapat bermanfaat bagi masyarakat kel.kambu dan sekitarnya.

\section{Rekrutmen Peserta}

Rekrutmen peserta KKN tematik terintegrasi pengabdian dosen, akan dilakukan secara terbuka dan transparan kepada mahasiswa. Persyaratan peserta yang dapat mengikuti kegiatan ini adalah mahasiswa yang memiliki kelayakan akademik berupa, IPK.3.00 keatas, jumlah SKS lulus, tahun semester dan kecakapan dalam kegiatan pelatihan manajemen komunikasi dan pembuatan alat peraga komunikasi tentang pencegahan pengenalan Covid-19 dan tujuannya untuk membentuk aparat yang kemandirian dalam menangani penyebaran Covid-19.

\section{Pembekalan Mahasiswa}

Pembekalan mahasiswa peserta KKN Tematik bertujuan untuk memberikan pengayaan dan pemahaman dasar terkait dengan program kerja, fokus, dan sasaran program yang akan dicapai pada kelompok sasaran yang dituju. Pembekalan kegiatan akan dilakukan secara online melalui aplikasi zoom dan whatsapp group yang telah dipersiapkan selama 2 (dua) hari kerja dengan durasi 120 menit, secara berturut-turut. Pembekalan direncanakan berlangsung dalam 2 (dua) tahap, yakni; 
1. Tahap pertama, pembekalan kegiatan terdiri dari materi umum dan materi khusus, teknik pembuatan alat peraga covid-19 dan pengenalannya pada masyarakat.

2. Tahap kedua, tim akan membentuk kelompok untuk mempraktekkan cara pembuatan alat peraga komunikasi dalam menghadapi Pandemi covid-19, berdasarkan fakta-fakta yang ada dilapangan sesuai denga sasaran (Aparat yang telah ditentukan sebelumnya) dalam bentuk teks, gambar, poster, Baliho, Banner dan Stiker.

\section{Hasil Dan Pembahasan}

Hasil yang sudah di capai yaitu, (1) Pemberian informasi mengenai Covid-19 melalui pamflet, poster dan brosur di Kelurahan Kambu Kecamatan Kambu Kota Kendari (fotofoto terlampir) (2) Sosialisasi gerakan masyarakat hidup sehat (GERMAS) di Kelurahan Kambu Kecamatan Kambu Kota Kendari (foto-foto terlampir) (3) Sosialisasi perilaku hidup bersih dan sehat (PHBS) di Kelurahan Kambu Kecamatan Kambu Kota Kendari i(foto-foto terlampir). (4) Membuat video penanaman serta pemanfaatan tanaman obat keluarga (TOGA) di Kelurahan Kambu Kecamatan Kambu Kota Kendari (foto-foto terlampir) (5) Artikel ilmiah (berita) yang dipublikasikan melalui SULTRAKINI.COM. (foto atau link terlampir) (6) Publikasi pada media online (7) Produk yang dihasilkan berupa pamflet, poster, brosur, dan khasiat tanaman TOGA (foto dan video terlampir).

Coronavirus merupakan virus RNA strain tunggal positif, berkapsul dan tidak bersegmen. Corona virus tergolong ordo Nidovirales, keluarga Corona viridae. Corona viridae di bagi dua sub keluarga dibedakan berdasarkan serotipe dan karakteristik genom. Terdapat empat genus yaitu alpha coronavirus, betacoronavirus, deltacoronavirus dan gamma coronavirus.

Tanda-tanda dan gejala klinis yang dilaporkan sebagian besar adalah demam, dengan beberapa kasus mengalami kesulitan bernapas, dan hasil rontgen menunjukkan infiltrate pneumonia luas di kedua paru-paru. Manifestasikl ini biasanya muncul dalam 2 hari hingga 14 hari setelah paparan. Pada kasus yang beratdapatmenyebabkan pneumonia,

sindrompernapasanakut, gagalginjal dan bahkan kematian. Seperti penyakit infeksi saluran pernapasan lainnya, 2019-nCOV dapat menular melalui percikan saat bersin atau 
batuk. Hingga saat ini belum ditemukan vaksin maupun obat untuk 2019-nCOV. Pengobatan dilakukan untuk meringankan gejala dan meningkatkan daya tahan tubuh.

Penularan dan bahaya Covid-19 yaitu covid-19 tersebar melalui ketika anda bersentuhan dengan cairan dari mulut penderita. Anda dapat terjangkit virus ini ketika terinfeksi dari batuk dan bersin penderita, menyentuh wajah setelah terkontak dengan cairan dari mulut penderita, atau menyentuh barang yang telah ada cairan dari mulut penderita. Pada kasus yang lebih parah infeksi ini menyebabkan pneumonia, sidrom pernapasan akut, gagal ginjal hingga kematian. Oleh karena itu, maka dilakukan beberapa langkah untuk mencegah penyebaran Covid-19 diantaranya, gerakan masyarakat hidup sehat (GERMAS), perilaku hidup bersih dan sehat (PHBS), menggunakan masker dan jaga jarak, penggunaan anti septik dan desinfektan dari bahan alam dan pemanfaatan tanaman obat keluarga.

\section{Gerakan Masyarakat (GERMAS)}

Gerakan masyarakat hidup sehat (GERMAS) merupakan gerakan nasional yang diprakarsai oleh presiden RI yang menghendakan upaya promotif dan prepentif, tanpa mengesampingkan upaya kuratif, rehabilitative dengan melibatkan seluruh komponen bangsa dan memasyarakatkan paradigm sehat. Untuk menyukseskan GERMAS, tidak bisa mengandalkan peran sector kesehatan saja. Peran kementerian dan lembaga di pusat turut menentukan dan ditunjang peran serta seluruh lapisan masyarakat. Mulai dari individu, keluargaan masyarakat dalam memperaktekkan pola hidup sehat, akademisi, dunia usaha, organisasi kemasyrakatan dan organisasi profesi dalam menggerakkan anggotanya untuk berperilaku sehat, serta pemerintah baik di tingkat pusat maupun daerah dalam menyiapkan sarana dan prasarana pendukung, dan mengevaluasi pelaksanaannya. GERMAS harus dimulai dari keluarga, karena keluarga adalah bagian terkecil dari masyarakat yang membentuk kepribadian, mulai dari proses pembeajaran menunjuk kemandirian.

Program KKN Tematik dari Tim GERMAS, dilaksanakan dengan mengadakan sosialisasi gizi seimbang untuk meningkatkan imunitas tubuh, sosialisasi mengenai pentingnya olahraga, dan sosialisasi mengenai bahaya merokok terkaid covid-19 di desa 
Sumber Rejeki Kecamatan Watubangga Kabupaten Kolaka yang bertujuan untuk menggerakkan masyarakat dalam melakukan pola hidup sehat kepada seluruh elemen masyarakat.

Sosialisasi yang dilakukan menggunakan 3 cara, yang pertama dengan mengumpulkan massa. Sosialisasi yang kedua dengan cara dari rumah kerumah (door to door). Sosialisasi yang terakhir dengan cara membagikan pamphlet maupun brosur serta penempelan brosur di rumah warga.

1. Kegiatan pertama yaitu sosialisasi dengan mengumpulkan massa/warga sebanyak 15 orang beserta dengan kepala desa, sekretaris desa, maupun aparat desa yang bertempat di balai desa Sumber Rejeki. Kegiatan sosialisasi yang dilakukan berjalan baik dan lancar. Masyarakat sangat mengapresiasi tim kkn tematik kabupaten kolaka menyelenggarakan sosialisasi di desa mereka. Kegiatan ini juga dilakukan sesuai dengan protocol kesehatan.

2. Kegiatan kedua yaitu sosialisasi dengan cara door to door. Sosialisasi ini dilakukan di karenakan tidak semua masyarakat di Desa Sumber Rejeki mengetahui sosialisasi yang telah di lakukan oleh tim kkn di balai desa. Maka kami melakukan sosialisasi dengan cara door to door agar semua masyarakat dapat menjaga kesehatan dengan makan-makanan yang bergisi, selalu berolahraga yang cukup dan rutin serta berhenti merokok dalam menghadapi covid-19.

3. Kegiatan ketiga yaitu, sosialisasi dengan menggunakan media pamphlet, brosur maupun poster. Media pamflet, brosur maupun poster juga sangat efektif dan dapat menumbuhkan kegemaran membaca masyarakat.

\section{Perilaku Hidup Bersih dan Sehat (PHBS)}

Salah satu upaya menuju kearah perilaku sehat dengan melalui satu program yang dikenal dengan program perilaku hidup bersih dan sehat (PHBS) yang dilaksanakan secara sistematis dan terkordinir. Sebelum melakukan kegiatan KKN tematik, tentang upaya Penguatan Peran Warga Masyarakat Dalam Mitigasi Dan Adaptasi Menghadapi Covid-19 Di Kota Kolaka, kami meminta persetujuan kepada kepala desa Sumber Rejeki untuk melakukan rangkaian kegiatan sosialisasi kepada masyarakat setempat. 


\section{Sosialisasi pencegahan Covid-19 melalui PHBS kepada warga}

Salah satu program KKN tematik yang dilaksanakan yaitu sosialisasi tentangphbs (perilaku hidup bersih dan sehat). Perilaku hidupbersih dan sehat (PHBS) merupakan bentuk perwujudan untuk memberikan pengalaman belajar atau menciptakan suatukondisi yang kondusif bagi perorangan, keluarga, kelompok dan masyarakat untuk meningkatkan pengetahuan, sikap dan perilaku agar dapat menerapkan cara-cara hidupsehat dalamr angka menjaga, memelihara, dan meningkatkan kesehatan. Perilaku hidup bersih dan sehat (PHBS) selama masa pandemikadalah program khusus dari dar ipemerintah Indonesia. Tujuannya adalah meningkatkan kualitas kesehatan masyarakat Indonesia secara keseluruhan. Diharapkan setiap individu menjadi sadar atas kesehatan dan mampu menjalankan perilaku bersih dan sehat dalam kehidupan sehari-hari selama masa pandemi Covid-19 yang sudah menyebar di dunia, termasuk di indonesia (Ganidkk., 2015).

\section{Sosialisasi dan pelatihan mengenai cara cuci tangan yang baik dan benar}

Melalui pengabdian KKN tematik dengan melakukan sosialisasi mengenai penguatan masyarakat dalam menghadapi pandemi Covid-19 dengan mensosialisasikan upaya untuk memutus rantai penyebaran rantai Covid-19, salah satu kegiatan yang di laksanaanya itu sosialisasi di warga desa Sumber Rejeki. Materi yang di sajikan adalah materi penyuluhan tentang cuci tangan yang baik dan benar dengan sabun dan air mengalir. PHBS mendukung kebersihan pribadi dan menghindari penularan berbagai penyakit melalu itangan yang terkontaminasi kuman.Pemberian materi ini di harapkan memberikan pemahaman kepada warga tentang pentingnya mencuc itangan menggunakan sabun dengan air mengalir sebelum dan sesudah melakukan aktivitas dan cuc itangan sebelum dan sesudah makan. Kegiatan tersebut dapat berjalan dengan baik dan lancar. Warga sangat antusias dan dapat bekerja sama dengan baik, serta dapat mempraktikkan mencuci tangan dengan sabun menggunakan air mengalir. 


\section{Sosialisasi pembagian pamflet, brosur dan penempelan poster dirumah warga}

Sosialisasi dilakukan kerumah-rumah warga sekaligus pembagian leaflet dan brosurser penempelan poster oleh tim KKN tematik UHO. Pembagian leaflet dan brosur serta penempelan poster diharapkan mampu memberikan informasi mengenai PHBS (perilaku hidup bersih dan sehat) dan di harapkan dapat menjadi upaya dalam pencegahan Covid-19.

\section{Kesimpulan Dan Saran}

\section{Kesimpulan}

Kesimpulan pada laporan ini yaitu pentingnya peran masyarakat Kelurahan Kambu Kecamatan Kambu Kota Kendari dalam mengurangi penularan Covid-19. Adapun cara yang dapat dilakukan seperti menerapkan perilaku hidup bersih dan sehat contohnya makan-makanan yang bergizi, olahraga yang teratur, dan istirahat yang cukup. Kemudian Menggunakan masker dan jaga jarak saat bepergian, serta memanfaatkan tanaman herbal yang terdapat disekitar lingkungan masyarakat Kelurahan Kambu Kecamatan Kambu Kota Kendari.

\section{Saran}

Saran dari kegiatan ini yaitu perlu dilakukan yang serupa guna keberlanjutan program kerja yang sudah dilaksanakan.

\section{Daftar Pustaka}

Gaffar, Afan. 1999. Politik Indonesia: Transisi Menuju Demokrasi. Jakarta: Pustaka pelajar.

Undang-undang Nomor 32 Tahun 2004 Tentang Pemerintahan Daerah 